\section{Differential Resistance Among Crape Myrtle (Lagerstroemia) Species, Hybrids, and Cultivars to Foliar Feeding by Adult Flea Beetles (Altica litigata)}

\author{
Raul I. Cabrera ${ }^{2}$, James A. Reinert, and Cynthia B. McKenney ${ }^{1}$ \\ Horticultural Sciences, Texas A \& M University Research \& Extension \\ Center, 17360 Coit Road, Dallas, TX 75252-6599
}

Additional index words. Altica litigata, crape myrtle, cultivars, Lagerstroemia, flea beetle, host resistance

\begin{abstract}
Field (choice) and laboratory (no choice) studies were conducted to evaluate the susceptibility of 12 crape myrtle (Lagerstroemia) cultivars, representing two species and their interspecific hybrids, to feeding damage by the flea beetle (Altica litigata Fall). The results indicate that as a group, the $L$. indica $L$. cultivars were more susceptible to attack and significant herbivory damage by Altica beetles, whereas all the $L$. fauriei Koehne cultivars and most of the interspecific $L$. indica $\times$ fauriei hybrids were resistant. Significant differences in feeding damage were observed between the new and older leaves in the susceptible hybrid 'Biloxi' and $L$. indica 'Whit IV', but not in the rest of the cultivars. Mineral nutrient content differences were observed between species with $L$. indica cultivars having a significantly contrasting nutrient status profile compared with the $L$. fauriei and interspecific hybrid cultivar groups. The results indicate that the factors influencing Altica flea beetle-feeding preferences and damage are inherited and therefore will allow the implementation of pest management practices that minimize damage and optimize chemical control strategies. In addition, opportunities may exist for breeding and selection efforts that could lead to superior cultivars with insect resistance.
\end{abstract}

The genus Lagerstroemia L. is native to Southeast Asia and comprises between 50 and 80 species, most of which are concentrated in tropical latitudes (Cabrera, 2004; Egolf and Andrick, 1978; Pooler, 2003). Of these, however, less than 10 species have been cultivated as ornamental plants, in particular $L$. indica L., L. fauriei Koehne, $L$. subcostata Koehne, and L. speciosa Pers. (Pooler, 2006b). Breeding and selection efforts in the United States, and specifically at the U.S. National Arboretum, have been instrumental in the development of modern cultivars that have the typical lengthy flowering period during the summer months and a diversity of flower colors as well as disease (powdery mildew) resistance, cold-hardiness, showy exfoliating bark, and a range of sizes (from $40 \mathrm{~cm}$ to greater than $6 \mathrm{~m}$ ) and growth habits (Pooler, 2003; 2006b). All these traits have led to a wide distribution and use of crape myrtles throughout southeastern U.S. gardens (Byers, 1997; Egolf and Andrick, 1978) and its categorization as a "naturalized" U.S. plant (Everett, 1981).

Received for publication 24 Aug. 2007. Accepted for publication 10 Oct. 2007.

${ }^{1}$ Current address: Department of Plant and Soil Science, Texas Tech University, Lubbock, TX 79409.

${ }^{2}$ To whom reprint requests should be addressed; e-mail r-cabrera@tamu.edu
Attesting to this status, in 1997, the common crape myrtle, $L$. indica, was designated as the official shrub for the state of Texas (Resolution 14, 75th Texas State Legislature).

The ruggedness and low-maintenance requirements of crape myrtles both in production and in the landscape have also been associated with relatively low insect and disease pressures. The very few insects that may regularly affect the appearance and performance of crape myrtles include aphids (Tinocallis kahawaluokalani Kirkaldy), Japanese beetle (Popillia japonica Newman), Florida wax scale (Ceroplastes floridensis Compsock), azalea bark scale Acanthococcus azaleae Comstock), and several species of flea beetles (Altica spp.) (Byers, 1997; Egolf and Andrick, 1978; Mizell and Knox, 1993). In recent years, there have been numerous reports by nursery growers of sudden and severe damage to young crape myrtle plantings by the Altica flea beetle with some reports of it becoming a serious pest in containerized nursery production throughout van de Mark, 2001; Pettis et al., 2004). A number of cultivated and weedy plants in the Oenothera, Calylophus, and Ludwigia (primrose) family and Lythracea (loostrife) family are the most common hosts for the primrose flea beetles (Altica litigata Fall) with both adults and larvae damaging the foliage in these plants (Center et al., 2002; McKenney, Reinert, and Cabrera, unpublished data; the southeastern United States (Braman and
Schultz et al., 2001). However, only the adult flea beetles have become a pest on crape myrtles, where substantial populations of this insect can suddenly appear and severely damage and defoliate young and containerized plants (Byers, 1997; Pettis et al., 2004). To date, there have been only limited and anecdotal reports of extensive flea beetle damage to landscape-established crape myrtles.

We report on the differential resistance of containerized liners of crape myrtle species and cultivars to a severe attack of flea beetles in a nursery setting, which was followed by a no-choice feeding trial in the laboratory to verify flea beetle-feeding preference.

\section{Materials and Methods}

Nursery choice feeding study. Rooted liners from 12 cultivars, all of standard size (greater than $6 \mathrm{~m}$ or greater than $20 \mathrm{ft}$ ) at maturity representing two Lagerstroemia species and their interspecific hybrids $(L$. indica, L. fauriei, and L. indica $\times$ L. fauriei hybrids) were acquired in early May 2002. Background information on these cultivars is provided in Table 1. The liners were transplanted on 27 May to No. 4 (12-L) plastic containers holding a 2 peat : 1 pine bark : 1 sand (by volume) growing medium amended with $3 \mathrm{~kg} \cdot \mathrm{m}^{-3}$ dolomitic limestone, $0.6 \mathrm{~kg} \cdot \mathrm{m}^{-3}$ of the micronutrient fertilizer Micromax (Scotts Co., Marysville, $\mathrm{OH}$ ), and $0.6 \mathrm{~kg} \cdot \mathrm{m}^{-3}$ of the wetting agent Aquagro (Aquatrols Corp. of America, Paulsboro, NJ). The plants were manually irrigated with a complete nutrient solution based on the water-soluble fertilizer Peter's Excel Cal- Mag 15-5-15 (Scotts Co.) adjusted to provide a nitrogen concentration of $100 \mathrm{mg} \cdot \mathrm{L}^{-1}$. The plants were placed in gravel beds lined with landscape fabric in an outdoor research nursery at the Texas A \& M Research and Extension Center in Dallas, TX. There were a total of five completely randomized blocks that included one plant of each cultivar per block. Plants of the cultivar 'Sacramento' (L. indica), which were acquired the previous season and were growing in 12-L containers, became heavily infested $\approx 29$ May with Altica litigata Fall flea beetles (Center et al., 2002) emigrating from nearby fields having large wild and cultivated populations of evening primroses (Oenothera spp.). On 30 May, one severely flea beetleinfested 'Sacramento' plant was placed in the middle of each block of the recently transplanted crape myrtle cultivars. Additional Altica beetles were collected from other infested plants and scattered evenly over the plants to increase the infestation potential of the plants in the experiment. Thereafter, data were taken for $4 \mathrm{~d}$ on the number of beetles per leaf (average of three leaves per plant) and leaf damage (percent of leaves damaged on each plant). The observations were made separately in older and newer leaves. Older leaves were those considered to be fully developed (i.e., fully expanded), whereas new leaves were those found in the tips of the growing shoots (tender, still in expansion). Two observers made each rating, 
which were then averaged per plant. Ten weeks after the end of this study, mineral analyses were performed in recently matured leaves collected from plants not exposed to the beetles. The nutrient analyses were done at the Louisiana State University AgCenter Soil Testing and Plant Laboratory with nitrogen measured by dry combustion in a Leco $\mathrm{CN}$ analyzer (LECO Corp., St. Joseph, MI) and the rest of plant essential elements done by inductively coupled plasmaspectroscopy in $\mathrm{HNO}_{3}-\mathrm{H}_{2} \mathrm{O}_{2}$ tissue digests.

Laboratory no-choice feeding study. Recently matured leaves were taken from terminal shoots of a pest-free block of plants containing seven of the Lagerstroemia cultivars used in the previous study. These leaves were used to bioassay the flea beetle adults in a no-choice laboratory experiment. The plants from which the leaves were taken were grown and culturally managed the same as in the previous study. Two freshly excised leaves of each cultivar were placed in feeding chambers consisting of $90 \times 20 \mathrm{~mm}$ (diameter $\times$ height) plastic petri dishes. Each dish was fitted with two water-saturated filter paper discs (75 mm diameter). During the experiment, water was added to the filter paper as needed to keep it saturated to help maintain leaf turgidity. Active adult flea beetles were taken from a colony of field-collected flea beetles, and five beetles were introduced into each petri dish. These beetles had been held in the laboratory for $10 \mathrm{~d}$ without any food or water before placement on the leaves in each feeding dish. Dishes were placed on a laboratory bench $\left(21 \pm 2{ }^{\circ} \mathrm{C}, 45 \pm 10 \%\right.$ relative humidity, and 14-h light : 10-h dark photoperiods with standard fluorescent lighting). The feeding chambers were arranged in a randomized complete block design with six replicates. Feeding damage (scored as percent of leaf area damaged in estimated 5\% intervals) and beetle mortality were assessed daily for $6 \mathrm{~d}$. Three observers rated the damage each day and the ratings were averaged.

Data analysis. Analyses of variance, orthogonal contrasts and mean separation procedures were performed using SAS software (SAS Institute, 2007). For statistical analyses of leaf damage percentage data in both experiments, data were transformed by taking the arcsine of their square root (Gomez and Gomez, 1984). Untransformed data are reported.

\section{Results}

Nursery choice feeding study. The flea beetles in the heavily infested 'Sacramento' plants in the midst of each block of crape myrtle liners were observed to immediately disperse to the liners. Within $24 \mathrm{~h}$, significant cultivar differences were observed with respect to the average number of beetles per leaf (Fig. 1). One and $3 \mathrm{~d}$ after the introduction of the flea beetle-infested 'Sacramento' plants, all the L. indica cultivars, 'Whit IV' (Red Rocket), 'Whit II' (Dynamite), 'Carolina Beauty', and 'Dallas Red', showed the highest flea beetle population densities, a combined daily average of 7.4 beetles per leaf. Conversely, all the L. fauriei cultivars, 'Kiowa', 'Townhouse', and 'Fantasy', had the lowest number of beetles per leaf, averaging less than 1 by day 3. The hybrid cultivars 'Natchez', 'Basham's Party Pink', and 'Tuscarora' had similar beetle numbers as the L. fauriei cultivars, except 'Biloxi', which had beetle numbers similar to the $L$. indica cultivars.

The percentages of leaves showing feeding damage after $3 \mathrm{~d}$ basically mirrored the observed number of beetles per leaf (Fig. 2) with 'Whit II' (Dynamite), 'Carolina Beauty', and 'Dallas Red' showing damage in greater than $90 \%$ of both their older and new foliage. These were followed by 'Whit IV' (Red Rocket), which, within the L. indica group, was the cultivar showing the least damage with $45 \%$ and $79 \%$ leaf damage to old and new leaves, respectively. Most of the L. fauriei and hybrid crape myrtles had little (less than 10\%) to no leaf damage, except the hybrid 'Biloxi', which had $98 \%$ and $17 \%$ feeding damage in its older and younger leaves, respectively. Analyses of variance and orthogonal contrasts of cultivars grouped according to species confirmed that $L$. indica cultivars were the most significantly infested and damaged by the flea beetles (data not shown).

Ten weeks after the end of this study, mineral analyses were conducted in recently matured leaves collected from liners (plants) not exposed to the beetles. The delay in conducting the tissue analyses was the result of the need to have sufficient leaf tissue mass to perform the analyses. Although it is

Table 1. Crape myrtle species and cultivars used in the Altica beetle nursery choice feeding study. ${ }^{\mathrm{z}}$

\begin{tabular}{|c|c|c|c|}
\hline $\begin{array}{l}\text { Lagerstroemia } \\
\text { species }\end{array}$ & $\begin{array}{c}\text { Cultivar name and } \\
\text { abbreviation }^{\mathrm{y}}\end{array}$ & Flower color & Origin/breeder \\
\hline L. indica & Carolina Beauty (CarolB) & Light red & Dailey's Nursery, SC \\
\hline L. indica & Dallas Red (DallRd) & Red & Troup Nursery, TX \\
\hline L. indica & $\begin{array}{l}\text { Whit II aka Dynamite }{ }^{\mathrm{TM}} \\
\text { (Dynmt) }\end{array}$ & Cherry red & Dr. Carl Whitcomb, OK \\
\hline L. indica & $\begin{array}{l}\text { Whit IV aka Red Rocket } \\
\text { (RdRkt) }\end{array}$ & Bright red & Dr. Carl Whitcomb, OK \\
\hline L. indica & Sacramento $^{\mathrm{x}}$ & Pink & Chopin Nurseries, LA \\
\hline L. fauriei & Fantasy (Fntsy) & White & NCSU Arboretum \\
\hline L. fauriei & Kiowa (Kiowa) & White & US National Arboretum \\
\hline L. fauriei & Townhouse (Twnhs) & White & NCSU Arboretum \\
\hline L. indica $\times$ faurie $i$ & Bashams Party Pink(BPPnk) & Lavender & $\begin{array}{l}\text { B. Basham \& L. Lowrey } \\
\text { (TX) }\end{array}$ \\
\hline L. indica $\times$ fauriei & Biloxi (Biloxi) & Pink & US National Arboretum \\
\hline L. indica $\times$ fauriei & Natchez (Ntchz) & White & US National Arboretum \\
\hline L. indica $\times$ fauriei & Tuscarora (Tscror) & Dark pink & US National Arboretum \\
\hline
\end{tabular}

zAll these cultivars are classified as "standard" size when mature (4.5 m or greater) with the exception of the dwarf Sacramento (less than $3 \mathrm{~m}$ ).

${ }^{\mathrm{y}}$ Abbreviation (in parentheses) used in figures.

${ }^{\mathrm{x}}$ One-year-old plants of this cultivar, heavily infested with primrose flea beetle (Altica litigata), were used to infest plants in each experimental block.

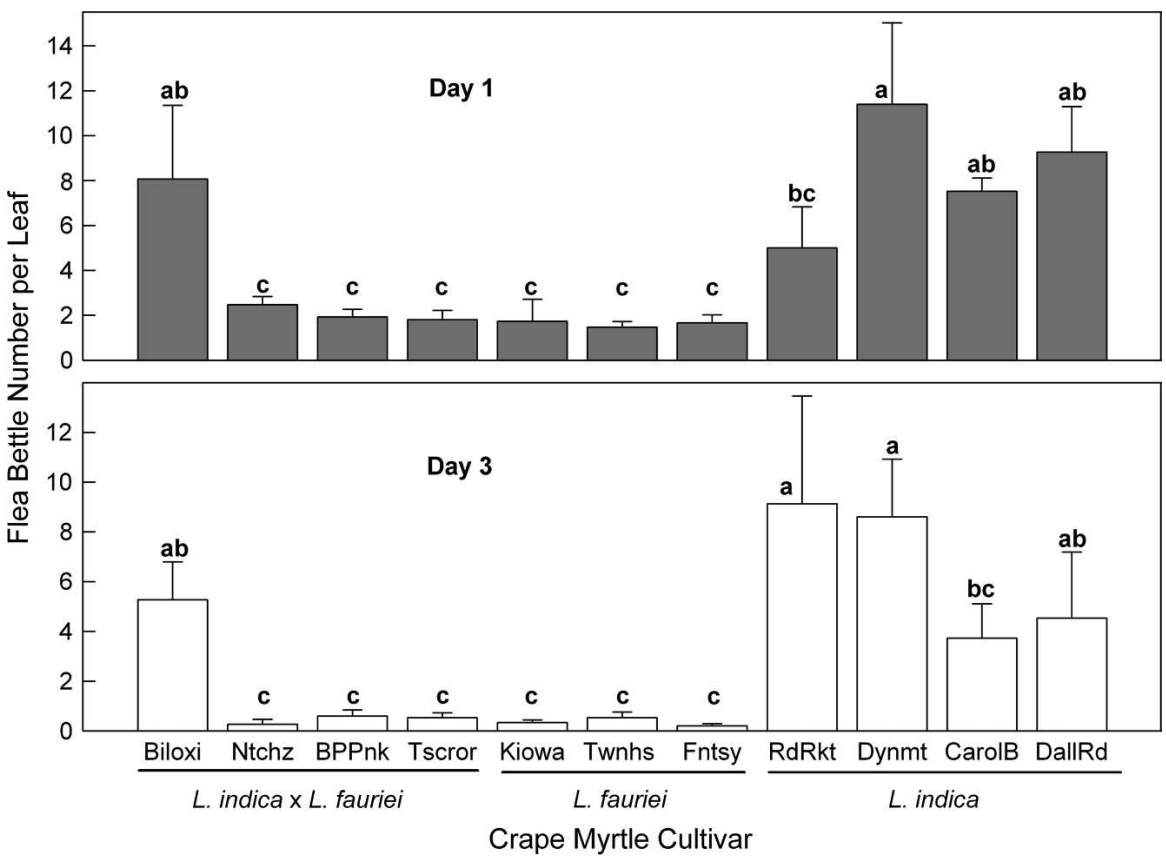

Fig. 1. Flea beetle (Altica litigata) infestation (number per leaf) in liners of selected crape myrtle cultivars growing outdoors in No. 4 (12-L) containers. Values shown are means of three leaves from each of five plants with cultivar means separation according to Duncan's multiple range test $(P<0.05)$. 


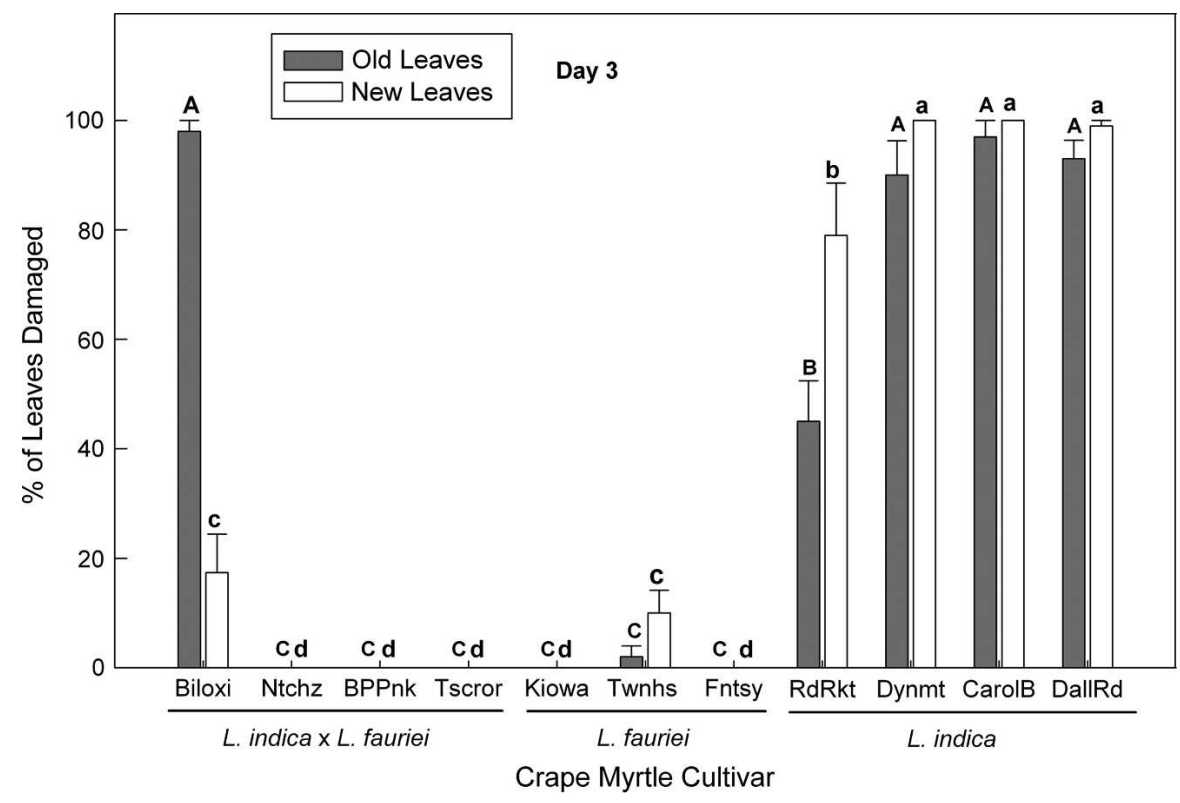

Fig. 2. Mean percentage of leaves damaged by flea beetle (Altica litigata) feeding in liners of selected crape myrtle cultivars growing outdoors in No. 4 (12-L) containers. Older leaves were those considered to be fully developed (i.e., fully expanded), whereas new leaves were those found in the tips of the growing shoots (tender, still in expansion). Values shown are means of five plants. Capital and lowercase letters were used for old and new leaves, respectively, to show cultivar mean separation according to Duncan's multiple range test $(P<0.05)$.

acknowledged that nutrient concentrations may have changed significantly over time, our attention was directed to an assessment of the overall nutrient profile differences in the species and cultivar groups and not specifically on actual concentrations of specific cultivars. Although nutrient concentration differences were indeed observed among individual cultivars (data not shown), grouping and statistical analyses by species (Table 2) showed that the $L$. indica cultivars had an overall and significantly contrasting nutrient status profile compared with the L. fauriei and hybrid cultivar groups. Significant leaf nutrient concentrations were found for nitrogen $(P=0.075)$ and phosphorus, potassium, boron, magnesium, and zinc $(P \leq 0.05)$.

Laboratory no-choice feeding study. Like in the previous trial, significant differences in leaf feeding damage were found among cultivars. The greatest feeding damage was observed in L. indica 'Dallas Red', which steadily increased over time up to $46 \%$ by day 5 (Fig. 3). In addition, this cultivar was the only one that had no dead beetles in its feeding chambers. In general, the beetles initially fed only on one leaf, but once they damaged it $\approx 25 \%$ to $33 \%$, they began feeding on the other leaf. Conversely, less than $1 \%$ leaf feeding damage was observed in the L. fauriei cultivars ('Kiowa', 'Fantasy', and 'Townhouse') after $5 \mathrm{~d}$, and $10 \%$ to $17 \%$ of the beetles were dead by this time, presumably as a result of starvation because the beetles had not fed for $15 \mathrm{~d}$, including the $10 \mathrm{~d}$ of no feeding before the laboratory study was initiated.

Within the hybrid cultivar group 'Basham's Party Pink' and 'Tuscarora' had very little leaf damage after $5 \mathrm{~d}$ (less than $1 \%$ ) and beetle mortality rates of $33 \%$ and $10 \%$, respectively. 'Natchez' also had little feeding damage by the beetles, $7 \%$ to $10 \%$ after $5 \mathrm{~d}$, and it was mostly observed as undersurface leaf tip or margin nibbling. Similar to the previous nursery choice trial, 'Biloxi' was the hybrid cultivar showing the greatest leaf feeding damage, $28 \%$ by day 5 , albeit it had produced beetle mortalities similar to the other hybrids (16.7\%).

Although mean comparisons of the beetle mortality data at day 5 were not significant when compared among all cultivars, orthogonal contrasts showed that 'Dallas Red' was significantly different from the group of hybrid cultivars $(P=0.05)$.

\section{Discussion}

In both the field choice study and the nochoice laboratory study, grouping of cultivars by species revealed a significant and damaging flea beetle-feeding preference on $L$. ind ica cultivars and herbivory resistance in all cultivars of $L$. fauriei and most of the interspecific hybrids (Figs. 1 and 2; Table 2). Our results are comparable to those presented by Pettis et al. (2004), who reported data from flea beetle choice trials done in commercial nurseries after they had outbreaks of Altica, plus other no-choice laboratory and controlled studies. For their outdoor choice trials, they evaluated beetle feeding on plants of different cultivars, phenological sizes (dwarf to standard), plant ages (months up to 3 years), and container sizes (12 to 95-L containers). From these trials they reported that, in general, the $L$. indica cultivars had the highest levels of feeding damage, and the least damage was found in those with $L$. fauriei parentage (namely the L. indica $\times$ fauriei hybrids). Braman and van de Mark (2001) also reported similar results in nochoice studies with caged flea beetles on crape myrtle cuttings.

Our study included the three commercially available pure $L$. fauriei cultivars, 'Fantasy', 'Towhnouse', and 'Kiowa' (Byers, 1997), and their performance leads to the contention that the flea beetle resistance trait observed in the majority of the interspecific hybrids was acquired from this parent species. Most of the hybrids trace their pedigree to one common $L$. fauriei parent, USDA PI 237884 (Byers, 1997; Pooler, 2003), and thus it may be presumed that many of the genotypical and phenotypical variations observed in the hybrids are likely to be more associated with the $L$. indica parents or other Lagerstroemia species (i.e., L. amabilis, L. limii) (Pooler, 2006b).

An analysis of the hybridization crosses and pedigrees of all the 24 interspecific hybrids released by the U.S. National Arboretum (Egolf, 1981a, 1981b, 1986a, 1986b, 1987a, 1987b, 1990a, 1990b; Pooler, 2006a; Pooler and Dix, 1999) plus the chance hybrid 'Basham's Party Pink' (Byers, 1997; Egolf and Andrick, 1978) coupled with all the

Table 2. Average leaf nutrient concentrations in crape myrtle cultivars grouped by species. ${ }^{\mathrm{z}}$

\begin{tabular}{|c|c|c|c|c|c|c|c|c|c|}
\hline & Nitrogen & Phosphorus & Potassium & Calcium & Magnesium & Iron & Boron & Manganese & Zinc \\
\hline Species & & & $(\%)$ & & & \multicolumn{4}{|c|}{$\left(\mathrm{mg} \cdot \mathrm{kg}^{-1}\right)$} \\
\hline L. indica & $2.60 \mathrm{a}$ & $0.31 \mathrm{a}$ & $1.98 \mathrm{a}$ & $1.79 \mathrm{~b}$ & $0.48 \mathrm{a}$ & $92 \mathrm{a}$ & $81 \mathrm{a}$ & $523 \mathrm{a}$ & $116 \mathrm{a}$ \\
\hline Hybrids & $2.64 \mathrm{a}$ & $0.27 \mathrm{a}$ & $1.68 \mathrm{~b}$ & $2.08 \mathrm{a}$ & $0.51 \mathrm{a}$ & $96 \mathrm{a}$ & $51 \mathrm{~b}$ & $382 \mathrm{~b}$ & $69 \mathrm{~b}$ \\
\hline L. fauriei & $2.80 \mathrm{a}$ & $0.28 \mathrm{a}$ & $1.74 \mathrm{~b}$ & $1.34 \mathrm{c}$ & $0.45 \mathrm{a}$ & $80 \mathrm{~b}$ & $47 \mathrm{~b}$ & $198 \mathrm{c}$ & $73 \mathrm{~b}$ \\
\hline Contrast & \multicolumn{9}{|c|}{ L. indica vs. hybrids plus L. fauriei } \\
\hline $\operatorname{Pr}>|t|$ & 0.075 & 0.027 & $<0.001$ & 0.270 & 0.985 & 0.288 & $<0.001$ & $<0.001$ & $<0.001$ \\
\hline Parameter estimate & -0.024 & 0.067 & 0.528 & 0.156 & 0.001 & 8.6 & 63.3 & 465 & 90.5 \\
\hline
\end{tabular}

${ }^{2}$ Data were taken 10 weeks after concluding the flea beetle (Altica litigata) feeding studies. There were four, four, and three cultivars for $L$. indica, interspecific (L. indica $\times$ fauriei) hybrids, and $L$. fauriei, respectively, with eight replicates per cultivar. Means within a column followed by different letters are significantly different according to Duncan's multiple range test $(P<0.05)$. 


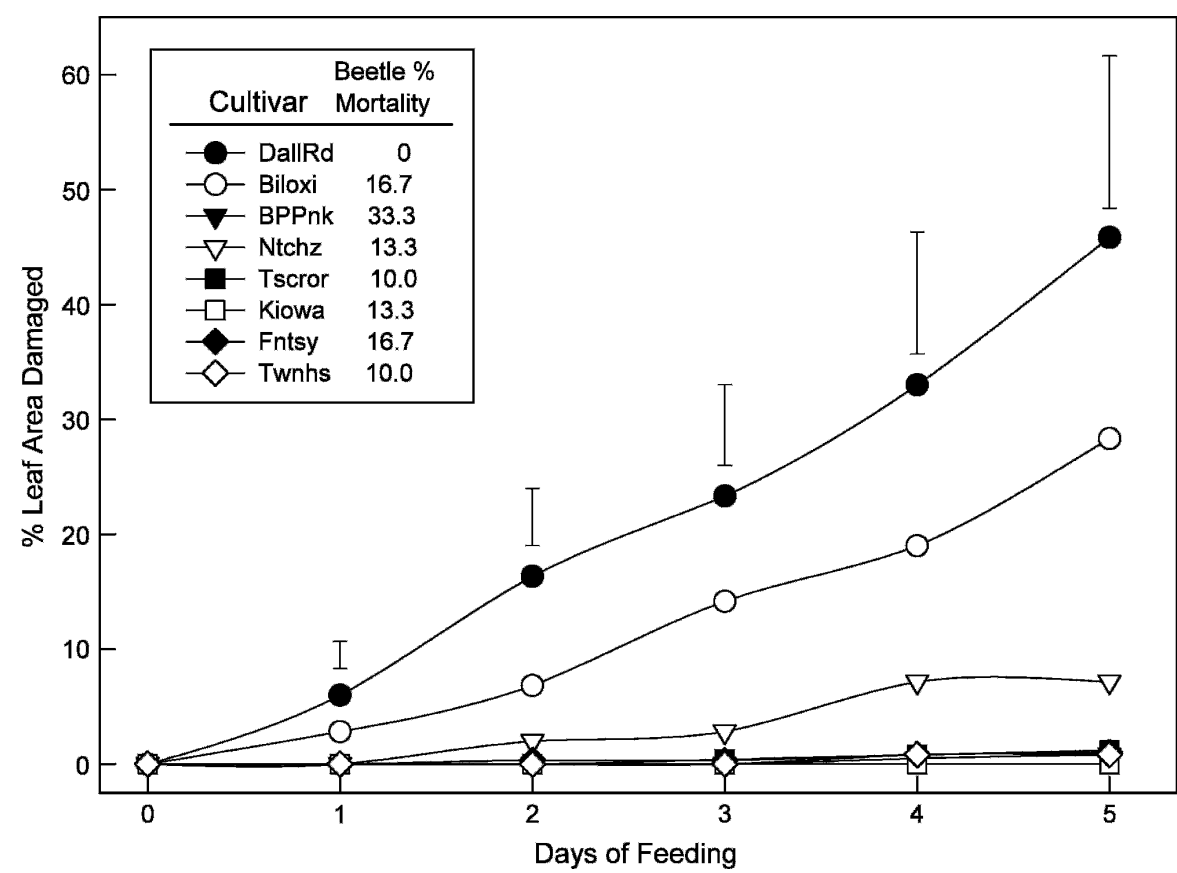

Fig. 3. Cumulative mean percentage of leaf area damaged by flea beetle (Altica litigata) feeding on detached leaves in petri dishes under laboratory conditions (no-choice feeding study). Values shown are means of six replicates. Vertical bar are least significant different values $(P \leq 0.05)$ for cultivar comparisons for each day. Cumulative beetle mortality data at day 5 are shown next to the cultivar legends.

currently available flea beetle resistance data, including our study, brings up the general observations that many of the taller cultivars and others with more complex hybridization schemes seem to have more flea beetle herbivory resistance. For instance, and rather interestingly, the semidwarf cultivars 'Hopi', 'Pecos', and 'Zuni' plus the standard-sized 'Biloxi', which have been previously reported as the only hybrids to show some susceptibility to powdery mildew (Hagan et al., 1998), have been rated also as susceptible or moderately susceptible to damage by Altica flea beetle (Pettis et al., 2004; our data in Figs. 1, 2, and 3). Analyzing their pedigrees, the commonality of these four cultivars is related to their dwarf $L$. indica parents ('Dwarf Red', 'Dark Red', 'Low Flame', and 'Alba Nana') and simpler hybridization crosses. There are other flea beetle-resistant crape myrtle hybrids that share up to two of these L. indica parents (i.e., 'Arapaho', 'Chickasaw', 'Pocomoke', 'Tonto'), but their pedigrees (hybridization schemes) are more complex, involving other medium to standard-sized $L$. indica parent cultivars/selections and even other Lagerstroemia species (i.e., L. limii in 'Arapaho'). Although further genetic studies using controlled hybridizations are necessary to test the genetic basis of these observations, they also merit further attention and consideration by horticulturists and entomologists.

As reported previously, 'Biloxi' was the only hybrid cultivar in our studies showing significant flea beetle damage and it was also reported as susceptible in one of the nursery trails (25-L containers) of Pettis et al. (2004). Perhaps as remarkable were the significant differences in feeding damage observed between the new and older leaves in 'Biloxi' (Fig. 2) and L. indica 'Whit IV' (Red Rocket). This differential feeding suggests significant changes or transitions in physical, biochemical, or physiological conditions as leaves age that affect Altica feeding preference on crape myrtle cultivars that are inherently susceptible to herbivory damage by this beetle. It has been postulated that changes in plant development affect the nutritional and defense qualities of a plant and could produce tissues with altered palatability or resistance to herbivores (Kearsley and Whitham, 1989; Schoonhoven et al., 2005). In line with this hypothesis, reports of Altica beetle damage on crape myrtles have been limited to young, rapid-growing plants (liners) under intensively managed nursery conditions, but not in mature, landscape-established plants. Cabrera and Devereaux (1999) previously reported that the intense fertilization and irrigation management of nursery-grown crape myrtles yield high leaf nutrient concentrations (i.e., lower $\mathrm{C}: \mathrm{N}$ ratio) that are significantly different in the same plants once they are transplanted and established into a landscape with minimum maintenance. Studies with other plants and beetle species indeed confirm that fertilization and irrigation management differentially affects plant nutrition and chemistry and the degree of insect preference and herbivory damage (Lower et al., 2003). Recent literature indicates that, in general, abiotic stresses on woody plants adversely affect the performance of chewing insects (Koricheva et al., 1998; Schoonhoven et al., plants with vigorous ("soft") growth and
2005) and that fertilization almost always decreases tree resistance to herbivore insects (Herms, 2002; Schoonhoven et al., 2005).

Regarding tissue nutrient status, the studies of Pettis et al. (2004) were not able to show correlations between leaf nutrient concentrations with Altica feeding damage in crape myrtles. Because nutrient concentrations were measured over 2 months after flea beetle herbivory resistance was assessed in our nursery choice feeding study, it is not possible to compare insect damage and plant nutrient correlations with those performed by Pettis et al. (2004). Nevertheless, our leaf mineral analyses data (Table 2) showed significantly contrasting nutrient profile differences between the $L$. indica cultivar group and the rest of the L. fauriei and hybrid cultivars. Although it is well known that the nutrient status of plants, particularly nitrogen, affects growth, development, and defense chemistry, the relationship between the total concentration of a mineral nutrient and insect-feeding preference or degree of damage is unclear and even conflicting (Beanland et al., 2003; Hargrove et al., 1984). Furthermore, most of these studies have focused on the link between individual plant nutrients and susceptibility to herbivory and have not considered the importance of more realistic multiple mineral-nutrient interactions. Some authors are embracing a mineral balance hypothesis that proposes that imbalances in the concentration and proportion of certain minerals impair primary or secondary metabolism to the point of enhancing a plant's insect susceptibility and the developmental performance of insect herbivores (Beanland et al., 2003). Unfortunately for crape myrtles, as with most ornamental and horticultural crops, in-depth studies with information and reference values of nutrient ratios that optimize plant growth, physiological performance, and defense mechanisms are lacking. Detailed studies are needed to link the integral nutrient status of a plant (i.e., nutrient concentration and ratios) with functional physiological/biochemical processes and the synthesis of metabolic products conferring resistance to insect damage (Schoonhoven et al., 2005).

In summary, our studies confirm the differential resistance of crape myrtle (Lagerstroemia) species and hybrids to herbivory damage by the flea beetle (A. litigata) The field and laboratory results indicate that as a group, cultivars of $L$. indica are more susceptible to attack and significant damage by primrose flea beetles, whereas $L$. fauriei cultivars and most of its interspecific hybrids with $L$. indica and other species are resistant. These results furthermore strongly suggest that the factors influencing flea beetle-feeding preferences are inherited and therefore offer the opportunity to help breeders and horticulturists to refine breeding and selection efforts to generate superior cultivars with insect resistance. The horticultural implications of these results are significant because they will allow growers to implement pest 
management practices that minimize damage and optimize chemical control strategies.

\section{Literature Cited}

Beanland, L., P.L. Phelan, and S. Salminen. 2003. Micronutrient interactions on soybean growth and the developmental performance of three insect herbivores. Environ. Entomol. 32:641651.

Braman, K. and G. van de Mark. 2001. Evaluation of crape myrtles for insect resistance. Research projects results. Center for Applied Nursery Research, Dearing, GA.

Byers, D. 1997. Crapemyrtle: A grower's thoughts. Owl Bay Publ., Inc., Auburn, AL.

Cabrera, R.I. 2004. Evaluating and promoting the cosmopolitan and multipurpose Lagerstroemia. Acta Hort. 630:177-184.

Cabrera, R.I. and D.R. Devereaux. 1999. Crape myrtle post-transplant growth as affected by nitrogen nutrition during nursery production. J. Amer. Soc. Hort. Sci. 124:94-98.

Center, T.D., F.A. Dray, Jr., G.P. Jubinsky, and M.J. Grodowitz. 2002. Water-primrose flea beetle, Altica litigata Fall (Coleoptera: Chrysomelidae: Halticinae), p. 140-143. In: Insects and other arthropods that feed on aquatic and wetland plants. U.S. Dept. Agr., A.R.S. Tech. Bull. 1870.

Egolf, D.R. 1981a. 'Muskogee' and 'Natchez' Lagerstroemia. HortScience 16:576-577.

Egolf, D.R. 1981b. 'Tuscarora' Lagerstroemia. HortScience 16:788-789.

Egolf, D.R. 1986a. 'Tuskegee' Lagerstroemia. HortScience 21:1078-1080.

Egolf, D.R. 1986b. 'Acoma', 'Hopi', 'Pecos' and 'Zuni' Lagerstroemia. HortScience 21:12501252.
Egolf, D.R. 1987a. 'Biloxi', 'Miami', and 'Wichita' Lagerstroemia. HortScience 22:336-338.

Egolf, D.R. 1987b. 'Apalachee', 'Comanche', 'Lipan', 'Osage', 'Sioux' and 'Yuma' Lagerstroemia. HortScience 22:674-677.

Egolf, D.R. 1990a. 'Caddo' and 'Tonto' Lagerstroemia. HortScience 25:585-587.

Egolf, D.R. 1990b. 'Choctaw' Lagerstroemia. HortScience 25:992-993.

Egolf, D.R. and A.O. Andrick. 1978. The Lagerstroemia handbook/checklist. Am. Soc. Botanical Gardens and Arboreta, Inc. Los Angeles, CA.

Everett, T.H. 1981. The New York Botanical Garden illustrated encyclopedia of horticulture. Vol. 6. Garland Publ. Inc., New York, NY.

Gomez, K.A. and A.A. Gomez. 1984. Statistical Procedures for Agricultural Research. 2nd ed. Wiley-Interscience, New York, NY.

Hagan, A.K., G.J. Keever, C.H. Gilliam, J.D Williams, and G. Creech. 1998. Susceptibility of crapemyrtle cultivars to powdery mildew and Cercospora leaf spot in Alabama. J. Environ. Hort. 16:143-147.

Hargrove, W.W., D.A. Crossley Jr., and T.R. Seastedt. 1984. Shifts in insect herbivory in the canopy of black locust, Robinia pseudoacacia, after fertilization. Oikos 43:322-328.

Herms, D.A. 2002. Strategies for deployment of insect resistant ornamental plants, p. 217-237. In: Wagner, M.R., K.M. Clancy, F. Lieutier, and T.D. Paine (eds.). Mechanisms and deployment of resistance in trees to insects. Kluwer Academic Publ., Dordrecht, The Netherlands.

Kearsley, M.J.C. and T.G. Whitham. 1989. Developmental changes in resistance to herbivory: Implications for individuals and populations. Ecology 70:422-434.

Koricheva, J., S. Larsson, and E. Haukioja. 1998. 1998. Insect performance on experimentally stressed woody plants: A meta-analysis. Annu. Rev. Entomol. 43:195-216.

Lower, S.S., S. Kirshenbaum, and C.M. Orians. 2003. Preference and performance of a willowfeeding leaf beetle: Soil nutrient and flooding effects on host quality. Oecologia 136:402411.

Mizell, R.F. and G.W. Knox. 1993. Susceptibility of crape myrtle, Lagerstroemia indica L., to the crapemyrtle aphid (Homoptera: Aphididae) in north Florida. J. Entomol. Sci. 28:1-7.

Pettis, G.V. D.W. Boyd, Jr., K. Braman, and C. Pounders. 2004. Potential resistance of crape myrtle cultivars to flea beetle (Coleoptera: Chrysomelidae) and Japanese beetle (Coleoptera: Scarabaeidae) damage. J. Econ. Entomol. 97:981-992.

Pooler, M.R. 2003. Molecular genetic diversity among twelve clones of Lagerstroemia fauriei revealed by AFLP and RAPD markers. HortScience 38:256-259.

Pooler, M.R. 2006a. 'Arapaho' and 'Cheyenne' Lagerstroemia. HortScience 41:855-856.

Pooler, M.R. 2006b. Crapemyrtle-Lagerstroemia indica, p. 428-449. In: Anderson, N.O. (ed.) Flower breeding and genetics. Issues, challenges and opportunities for the 21st century. Vol. 2. Springer, New York, NY.

Pooler, M.R. and R.L. Dix. 1999. 'Chickasaw', 'Kiowa' and 'Pokomoke' Lagerstroemia. HortScience 34:361-363.

SAS Institute. 2007. SAS system for Windows, release 9.1. SAS Institute, Cary, NC.

Schoonhoven, L.M., J.J.A. van Loon, and M. Dicke. 2005. Insect-plant biology. 2nd ed. Oxford University Press, Hampshire, UK.

Schultz, P.B., D.O. Gilrein, and M.S. Dills. 2001. Flea beetles damaging perennials. S. Nursery Res. Conf. Proc. 46:190-191. 